\begin{abstract}
Александра Костић Тмушић
Филозофски факултет

Универзитет у Приштини са привременим седиштем у Косовској Митровици

Међународни центар за православне студије, Нии

e-mail: aleksandra.kostic.tmusic@pr.ac.rs
\end{abstract}

\title{
Кристина Митић
}

Филозофски факултет, Универзитет у Нииу

Центар за византијско-словенске студије

e-mail: kristina.mitic@filfak.ni.ac.rs

\section{ПРЕСВЕТА БОГОРОДИЦА У УСМЕНОКНИЖЕВНОЈ ТРАДИЦИЈИ}

\author{
Ђе joj pacте по крај сриза дрвие, \\ У иирину по свему свијету, \\ У висину до ведрога неба.
}

(Караџић, 1866, 312)

Апстракт: Народни култ Пресвете Богородице разликује се од ирквеног већом обичношћу и укљученошћу у свакодневни живот. Пресвета Богородица је у новозаветним апокрифима вишеструко заступљена, ти мотиви се огледају у индексима мотива усменокњижевне традиције.

Кључне речи: Пресвета Богородица, народно веровање, народна поезија, народна проза

Етички усавршено хришћанство и паганско обожавање природе неодвојиве су нити наше народне религиозности. Примера ради, прослава Васкрсења и прослава пролећа једнако славе живот вечни - Христос побећује смрт, пролеће побеђује зиму. Духовна страна живота наглашенија је у првој врсти победе, док је у другој врсти победе наглашенија физичка страна живота. Наша народна религиозност и жилавост једнако су проткане високим идеалима човечанства, као и детињом свежином и непосредношћу. ${ }^{1}$

Усменокњижевна традиција је прихватила хришћанство и преобразила га $у$ сопственим оквирима уносећи елементе који нису, теолошки гледано хришћански. Варијантост и различити услови варијантности унели су промене у народну причу и у народну песму - „човек из народа не брине о строгој теолошкој исправности” приповеданог и певаног. Док Црква не дозвољава замењивање Господа Бога другим бићима у усменокњижевној традицији је то могуће 2 , па у етиолошким предањима, нпр., Бог ствара свет, али то једнако чини и Пресвета Богородица, као и други светитељи и

1 Уп. Чајкановић, 1994в, 151.

2 Уп. Ајдачић, 2005, 288, 292; Митић, 2018, 371-378. 
светитељке. Такође, у народној песми вилу замењује Богородица, коју често замењују Света Недеља, али и друге светитељке.

„Психолошки основ поштовања Богородице код Срба лежи у њиховом менталитету и тешкој историји. У људској је психологији да се у невољи прибегава заштити пријатеља, зато је почашћена епитетом Пресвета и атрибутима Путеводитељица, Наставница, Брза помоћница, Добротворка и сл. [...] Богородица се сматра за милосрдну и предусретљиву, за небеску заступницу као и заштитницу људи од несрећа и болести, покровитељку породиља. Назива се још Богомајка, Богоматер, Богомати, Богородитељка, Владичица, Мајка Божја, Пресвета, Пречиста [...]”3

Дан када су Свети Јоаким и Ана зачели, после толико година неплодног брака, будућу Богородицу, назива се у Лужници - „Анино зачатије”4, у Лесковачкој Морави „Јањино зачеће”, и празнује се 9. децембра / 22. децембра. ${ }^{5}$ У Хомољу трудне жене нису смеле читав дан руке преко трбуха да ставе. Погрешно се веровало у народу да је овог дана Пресвета Богородица остала трудна са Исусом Христом и да га је носила годину и шеснаест дана. ${ }^{6}$ „Христос се зачео у деви Марији, као што зрно бадема постаје у својој тврдој неповређеној коштици. Зато је ореола око Девине иконе с малим Христом на руци често бадемастог облика."7

Међу дванаест великих Господњих празника четири су Богородичина: Рођење Пресвете Богородице, Ваведење Пресвете Богородице, Благовести и Успење Пресвете Богородице. ${ }^{8}$ Народна религија особито поштује још четири Богородичина празника: Сабор Пресвете Богородице, Полагање ризе Пресвете Богородице, Полагање појаса Пресвете Богородице и Покров Пресвете Богородице. ${ }^{9}$

Календарски први Богородичин велики празник јесу Благовести (25. марта / 7. априла). Према народном казивању из Груже - то је толико велики празник, да ни птице тога дана не савијају своја гнезда, тј. строго су забрањени сви послови ${ }^{10}$. Жене нероткиње ишле би на Благовести у цркву како би рађале. ${ }^{11}$ Пагански празник посвећен божанству плодности могуће је повезати са хришћанским представама и значењима дана када је Пресвета Богородица примила благу вест и дознала да је у благословеном стању. ${ }^{12}$ У народу се о Благовестима гатало о времену - у Поповом Пољу у Херцеговини веровало ce: „ако на тај дан скваси киша волу рог, веле да ће те године бити добар род."13 У Алексиначком Поморављу се веровало - ,ако је сунчан дан, година ће бити родна и за људе здрава."14

Први петак по Васкрсу - источни, светли, благи, бели петак, пре зоре ишло се на источник или извор, који је на источној страни места у ком се живи. Ту се умивало и у три маха пребацивала вода преко себе шакама. ${ }^{15}$ Почетком двадесетог века православни

3 CE, 2011, 268.

4 Николић, 1900, 91.

5 Ђорђевић, 1958, 399.

6 Милосављевић, 1914, 68.

7 Нишевљанин, 1990, 11.

8 У неким изворима се том низу додаје и пети празник - Сретења Господњег, уп. СЕ, 2011, 268.

9 Уп. Недељковић, 1990, 32, 256.

10 Петровић, 1934, 241.

11 Исто.

12 Недељковић, 1990, 28-29. Уп. Чајкановић, 1994a, 164-170, Чајкановић, 1994б, 325-332; Самарџија, 2011, 394.

13 Мићовић, 1952, 157.

14 Антонијевић, 1971, 185.

15 Милићевић, 1984, 107. 
из Сарајева рано су ишли на источник Бендбашу и умивали се на извору Пјенковац, верујући да је то добро ради здравља јер је тога дана и „Богородица измивала Христу ране". ${ }^{16}$

Наредни Богородичин празник, особито поштован у народу, јесте Полагање ризе Пресвете Богородице (2. јула / 15. јула). Он има у народу и различите називе: у Попову Пољу у Херцеговини зове се „Петрова мати”17, док се нпр. у Хомољу зове „Рези-појас”18. Тај дан строго су били забрањени тзв. женски послови: није се плело, ткало, шило, нити се бојила пређа, такође се жене нису чешљале нити прале косу. Налаза из традиције о овом празнику има и у серијској публикацији „Zbornik za narodni život i običaje južnih Slavena”, где нпр. 1915. стоји забележено: „Kažu, da je neka žena prala taj dan pa rekla: 'Ja ću prati; ne bojim se, neka riza rizika, a verige neka verugaju!' I odma' da je snašlo. Svještavali joj, popovi masla, i vodili je pod evanđelje, dok je došla na šest."19

Уочи Малог Крстовдана, који пада 1. августа / 14. августа и који је први дан Госпојинског поста, празнују се Госпојинске покладе, после којих настаје двонедељни пост. $^{20}$ У народу је поштован Госпојински пост, сматран је наставком Великог поста. ${ }^{21}$ Овај двонедељни пост уочи Велике Госпојине има неколико народних назива - од Лесковачке Мораве до Фрушке горе зове се „Госпођини пости”22, „Панађурски пост”23 зове се у неким местима код Пирота, у Горњој Пчињи носи назив - „Богородичин пост”24 - тамо се причало: „како су неки, који нису хтели да посте тај пост, ишли и где год су дошли да пију воду, вода им се претварала у крв., 25

Госпојинске покладе и Госпојински пост падају две седмице уочи Велике Госпојине - Успења Пресвете Богородице. Време од Велике Госпојине (15. август / 28. август) до Мале Госпојине (8. септембра / 21. септембра) народ зове „међудневица” и то је време „биљобрања”. Беру се лековите траве, које се употребљавају за бајање „против ветрова који наносе болести" 26 . На Велику Госпојину би болесници одлазили на „видарице” (посвећене изворе који имају лековиту моћ) да се пре сунца умију водом ради оздрављења. ${ }^{27}$ Према предању Господ је узнео тело Пресвете Богородице на небо, чиме је њен гроб постао лествица за небо. ${ }^{28}$

Полагање Појаса Пресвете Богородице (31. августа / 13. септембра) у околини Бољевца празнују трудне жене да би лакше рађале децу. ${ }^{29}$ „Одевни предмети који покривају део тела са већ развијеним значењем 'заштите', по правилу добијају исту симболичку вредност.” 30 „У Гружи жену пред порођајем унапред опасују канапом који је

16 Брканлија Касаблија, 1903, 170.

17 Мићовић, 1952, 164.

18 Милосављевић, 1914, 63.

19 Ardalić, 1915, 50.

20 Jovićević, 1928, 314.

21 Грбић, 1909, 9.

22 Филиповић, 1934, 96.

23 Ђорђевић, 1899, 77.

24 Филиповић, Томић, 1955, 99.

25 Исто, 100.

26 Према: Недељковић, 1990, 48.

27 Петровић, 1934, 254.

28 CЕ, 2011, 268. Вид. и Krstić, 1984, 44: В 3, 8, 6 Kad Marija umre, ponesu je četiri evanđelista. Sretne ih Isus i kaže da njegova mati nije zaslužila da trune u zemlji, nego neka je odnesu na nebo.

29 Грбић, 1909, 72.

30 Мршевић Радовић, 1987, 312. 
сву ноћ висио у цркви поред иконе Богородице". ${ }^{31}$ Појасеве освештане над Појасом Пресвете Богородице, који се чува у Манастиру Ватопед на Светој Гори, носе бездетни супружници држећи особито правило поста. Поводом глагола опасати се, Вук у „Рјечнику” наводи и један пример његовог метафоричног значења - „опасао се снагом”. Вук је упутио и на локализам „пас” који се употребљава у два значења - у значењу „појас” ( А уз тебе од злата пасове) и у значењу познатом са подручја Црне Горе „кољено у роду” (први пас, други итд.). ${ }^{32} \mathrm{У}$ „Српском митолошком речнику” о појмовима појас, nâc и опасивање писао је Петар Ж. Петровић: „На дан венчања девојка се опаше мушким појасом, да би рађала мушку децу. Пошто први пут уђе у младожењину кућу, она се провуче кроз мушки појас у истој тежњи. На Бадње вече чобанин постави свој појас на улаз у тор, да преко њега пређе стока, па га затим опаше око себе. [...] Опасивање, магијско - често се примењује у народу: опасују се невесте и нероткиње да би затруднеле, труднице да би лако родиле, породиља и дете да се не урекну, болесници да би оздравили, здрави да задрже здравље, кућа, пчеланици, торови и воћке да би се заштитили од демона, цркве да би се умилостивила божанства, гробови да би се завезали мртваци за гроб због вампирења.”33 Ана Плотњикова у енциклопедијском речнику „Словенска митологија” пише да је народ веровао како нас одсуство појаса чини слабима и незаштићенима и да је семантика опасивања блиска семантици појаса - почива на веровању у магичну заштитну моћ затвореног круга. ${ }^{34}$

Празник рођења Пресвете Богородице (8. септембра / 21. септембра) у народу се назива Мала Госпојина, Мала Госпођа или Мала Богородица. ${ }^{35}$ у хомољском крају је било уобичајено да од Мале Госпође сељаци почињу орати и сејати озиме усеве, а у банатским херским селима око Мале Госпојине су одржавали овновске свадбе: „три недеље пре празника одвоје се овнови од оваца, држе их код куће и боље их хране. Око празника ти овнови се оките и пуштају међу овце, претходно их јашу женска деца, да би према веровању, и јагањци били женски". ${ }^{36}$

Празник Богородичиног покрова, веома раширен у Русији, дошао је у наше крајеве под руским утицајем. Установљен је 911. године, када је по хришћанском учењу Пресвета Богородица виђена у Влахернској цркви у Цариграду како се моли Христу за цео свет, покривајући својим омофором хришћане. ${ }^{37}$ „Покровица” (1. октобра / 14. октобра) првенствено је женски празник. Жене које рађају, посте седам дана пред овај празник да би лакше рађале. ${ }^{38}$ У Лесковачкој Морави тад не раде жене ни рукама ни у баштама, а нарочито не труднице ${ }^{39}$, док у Височкој нахији нико није радио тога дана. ${ }^{40}$ Ни у околини Бољевца жене нису на „Покровицу” ништа радиле од ручних радова ${ }^{41}$, а у Левчу и Темнићу ни мушкарци ни жене нису радили на „Покровицу”, а многи за овај дан посте седам дана ради здравља у кући, ${ }^{42}$ тај пост носи у народу исто име - „Покровица”.

31 Петровић, 1934, 254.

32 Караџић, 1986; 1972.

33 CMP, 1998, 73.

34 CMEP, 2001, 433-434. Уп. Љубинковић, 2014, 329-337.

35 Грбић, 1909, 72, Урошевић, 1990, 100.

36 Милосављевић, 1915, 65, БХ, 1958, 313.

37 Према: Недељковић 1990, 185, 32.

38 Петровић, 1934, 254.

39 Ђорђевић, 1958, 393.

40 Филиповић, 1949, 142.

41 Грбић, 1909, 73.

42 Мијатовић, 1907, 140. 
У више крајева је празник Ваведења, који пада 21. новембра / 4. децембра, познатији под називом „Пречиста”, поготову по југоисточној Србији. ${ }^{43}$ Тад не раде нарочито младе жене које рађају, и нероткиње да би родиле. У Лесковачкој Морави нероткиње одлазе овога дана у Манастир „Свете Богородице” у Црковници и пошто тамо преспавају, провлаче се, пре сунца, испод једне старе букве - да би родиле. ${ }^{44}$ У бољевачким селима се Ваведење празнује због вукова: овога дана се маказе не узимају у руке, „да би вуцима остала уста склопљена"45, а у Хомољу Ваведење нарочито поштују они који имају доста стоке. ${ }^{46}$ О Ваведењу су у Неготинској крајини предсказивали време: ако је тога дана киша - година ће бити берићетна, ако је пак ветар или магла, онда је неродна. ${ }^{47}$ У Крагујевачкој Јасеници важило је правило за оне који су те године ожењени, да још тога дана смеју играти око девојака, и више никад. ${ }^{48}$

\section{Пресвета Богородица у усменопоетској традицији}

Теотоколошки мотиви присутни су у народној поезији и првенствено су повезани са народним веровањем о Пресветој Богородици, заштитници трудница и породиља. Међу песмама „побожним” Вукове пете збирке налази се песма која се певала „на сијелу уз четворо поста годишњијех”. Богородица сања да јој поред срца расте дрво, а значење тог сна протумачи јој њен брат:

\section{$[\ldots]$}

„Што ти расте украј срияа дрвие,

„,То ћеш родит' Христа Бога сина;

„Што се дрвие широм раширило

„И покрило с крај на крај свијета,

„, То ће свијет од гријеха спасти,

„Што се дрвие к небу узвисило,

„Са земље ће оиу Богу поћи. "49

Чудесно зачеће Христа распрострањен је фолклорни мотив, сама Пресвета Богородица је, према народним представама, зачета од мириса цвећа, она је Христа зачела миришући бели крин. ${ }^{50} \mathrm{O}$ Христовом рођењу највише се може наћи у апокрифима, али и у народној традицији. Дванаест дана пре Божића називају се мучним данима. Према запису у оклини Бољевца, народ верује да се у ове дане замучила Пресвета Богородица да роди. Зато у ове дане трудне жене ништа не раде. ${ }^{51}$

43 Према: Недељковић 1990, 190.

44 Ђорђевић, 1958, 398.

45 Грбић, 1909, 75.

46 Милосављевић, 1914, 67.

47 Димитријевић, 1901, 235.

48 Павловић, 1921, 99.

49 Караџић, 1866, 312-313. Варијанте према Krstić, 1984, 36, 40: В 2, 1 Nagoveštavanje i proricanje Hristovog rođenja. B 2, 1, 1 Anđeo javlja devi Mariji da će roditi sina. B 2, 1, 2 San predskazuje Bogorodici ili kome drugo da će roditi sina. B 2, 8, 6 Nasred zemlje je Hristovo drvo, a pod njim su, za trpezom, sveci i sestra Marija.

50 Krstić, 1984, 36: B 2, 2 Hristovo rođenje. B 2, 2, 1 Anđeo da devi Mariji ljiljan, ružu ili grozd. - Ona pomiriše i posle devet meseci rodi Hrista. В 2, 2, 2 Bogorodici se otvore grudi i ona rodi Hrista. УП. Вранска, 1940, 94-95.

51 Грбић, 1909, 77. 
Калинарке су, нпр. на ранилу ${ }^{52}$ од Игњатијевдана до Божића, према бележењима свештеника Дене Дебељковића, на Косову и Метохији, певале различите песме које се тичу живота Пресвете Богородице, тако је и са песмама на Ивањдан, који Божићу стоји у народном месецослову дијаметрално супротно, као зимски и летњи солстициј. За празник Ивањдан постоји још и назив Свети Јован Игритељ, каже се и зато што је он заиграо у утроби мајке кад се она срела и пољубила са Пресветом Богородицом. ${ }^{53}$ У Босни, у Височкој нахији, бранило се певање на Бадњи дан јер се тог дана Пресвета Богородица мучила у порођајним мукама с Христосом. ${ }^{54}$

У народној лирској поезији и апокрифима обред Христовог крштења изводи се у детињству ${ }^{55}$. Пресвета Богородица у том обреду игра главну улогу. Постоји низ народних лирских песама са мотивом „биљка помаже или одмаже Пресветој Богородици и бива награћена или кажњена". ${ }^{56}$ Богородица у усменокњижевној традицији благосиља, али више куне биљке и животиње, својим клетвама одређује особине биљног и животињског света. ${ }^{57}$ Мотив проклињања дрвећа, биља или птица од стране Пресвете Богородице или неког другог светитеља или светитељке пореклом је, такође, из апокрифа.

Коледари, мушке обредне поворке, које су о Божићу обилазиле насеобине зарад обредног певања за плодност и благосиљања нове године, певали су и о Богородичиним порођајним мукама, које трају „од Игњата до Божича” и о обреду Христовог крштења:

\section{Коледарска}

Замучи се Божја мајка,

Од Игњата до Божича,

Та си роди млада Бога,

Млада Бога и Божсича.

Никој не мож' да Ђи крсти,

Нити Бога ни Божсча,

Осем Јован Крститељу.

Стани, горо, стани, водо,

52 Вид. Митић, 2018а, 229-247.

53 Милићевић, 1984, 133.

54 Вид. Филиповић, 1949, 125.

55 Неки од мотива скочаних са Христовим детињством и Пресветом Богородицом су још и: В 2, 4, 1 Bogorodica sedi sa svecima za rajskom trpezom i u rukama drži Isusa. - Dunu vetrovi ili se svedu oblaci i odnesu ga. B 2, 4, 2 Bogorodica izađe iz kuće (da prostre pelene). - Kad se vrati, vidi da nema malog Isusa: uzeo ga je sebi Bog. B 2, 4, 4 Jevreji nateraju Bogorodicu da im pokaže malog Hrista, a onda ga stanu pljuvati i nad njim oštriti noževe. B 2, 4, 5 Bogorodica da malog Hrista grlici da ga pričuva. - Ona zaspi, a Jevreji ga ukradu. B 3, 1, 1 Božja majka pravi ljuljku da ljulja belog (mladog) Boga. B 3, 1, 2 Anđeli odnesu malog Hrista Bogu. Bogorodica plače, a iguman joj kaže da će joj dete doći kad prođu sedam četvrtaka. - Ona kune četvrtke što ne prolaze brzo (Krstić, 1984, 38, 41).

56 Уп. Krstić, 1984, 37, 43: В 2, 3 Hristovo krštenje. В 2, 3, 1 Bogorodica moli svece da joj krste sina. Oni kažu da ne smeju od Sv. Jovana (Ivana). Najzad sretne i njega i on krsti Hrista. B 2, 3, 5 Dok krštavaju Hrista sve stoji osim trepetljike, ovsa i prosa. Bogorodica ili Sv. Jovan proklinju trepetljiku da stalno treperi, a ovas i proso da se ne nose u crkvu i ne mese za dušu.

57 Самарџија, 2011, 290. Вид. Krstić, 1984, 43, 465. B 3, 5, 1 Bogorodica kune biljke (topolu, jablan, trepetljiku, jasiku, proso, ovas, svibu, gloginju, jelu, bor) da stalno trepere, da nemaju roda, da se ne nose u crkvu, što joj se ne uklanjaju s puta, ne poklanjaju se, ili što se ne umire, već trepere: Vuk I 197, V 248; Karadžić-Vrčević 341; T. Đorđević 12; SEZ VII, str. 271, br. 3; L. M. S. knj. 95, str. 112; Mijatović 187, 188; ZNŽ VII, str. 195; D. Đorđević, str. 272, br. 95): Božja majka vodi Hrista za ruku. Jela im se pokloni i ukloni. - Ona je blagoslovi da bude sveta i da se zeleni i zimi i leti $(\mathrm{B} 3,5,2)$ или Kukavica budi malog Isusa. - Bogorodica je proklinje da satlno kuka i da nosi jaja u tuđem gnezdu (B 3, 5, 3). Kad se Hristos rodi, mazga mu se naruga. - Bogorodica je prokune da nema poroda (B 2, 2, 6, B 3, 5, 4). 
Да крстимо намег Бога,

Намег Бога и Божича.

Што дочуло, све стануло,

И гората и водата.

Не станула трепетљика,

Таг Ђу Јован љуто проклел:

Трепетьићо, да трепериш,

И са ветар и без ветар. ${ }^{58}$

Сличне варијанте налазе се и у лазаричким песмама. Лазарице, женске обредне поворке које су насеобину обилазиле с краја Цветне недеље, певале су свим члановима заједнице помињући и Пресвету Богородицу:

\title{
Лазаричка
}

(nony)

Света Петка иркву мела,

Усред небо међу магле,

У юум поју девет попа,

Девет попа, девет Ђака

И дванајес калуђера.

Дочула ги божја мајка,

Па ги она говорила:

„Стани, водо, стани горо,

Да слушамо девет попа,

Девет попа, девет Ђака

И дванајес калуђера!"

Све стануло, престануло,

Трепетьика не станула.

Проклела гу божја мајка:

„Еj, дабогда, трепетљике,

Не станула, престанула,

Нити пород породила,

Само такој треперила!'”

Ој убава, мала момо! ${ }^{19}$

Краљице, исто женске обредне поворке из ускршње-тројичанског периода, у својим песмама су често помињале Пресвету Богородицу. Вилинско зидање цркве место града украјински је мотив. Богородица старога века је вила, ${ }^{60}$ а мотиви у којима се старија жена поистовећује са вилом која зида град на облаку, а потом на његовим вратима приређује свадбе свог сина и кћерке, митолошки су. ${ }^{61}$ Ни на небу ни на земљи гради се и троврата црква, граде је је свеци, светитељке, али и угледни старији људи, понегде је од винске пене граде голубови. ${ }^{62}$

\author{
Кра.ьичка \\ (женама) \\ Заспала ми божја мајка
}

58 Николић, 1910, 144-145. Варијанте: Prvulović, 1982, 15; Васиљевић, 1960, 12; Кожељац, 1978, 289.

59 Васиљевић, 1960, 47. Варијанте: Димитријевић, 1987, 28, 29; Ђорђевић, 1990, 36-37.

60 Према: Belaj, 2007, 374. УП. Krstić, 1984, 44: В 3, 6, 5 Bogorodica zida crkvu.

61 Јокић, 2012, 250-251.

62 УП. варијанте Димитријевић, 1987, 27, 28. 
насред неба, на облака.

Малко спала, сан гледала:

На сан иркву саградила, и при иркву једно дрво, једно дрво јаворово. Шума му је малинова, кора му је јаворова, слупке су му позлаћене.

Што је шума малинова, туј си мајка ћерку дава; што је кора јаворова, туј си мајка сина жени; што су слупке позлаћене, туј си мајка сама седи.

Ој убаве, мале моме, ладо, ладо! 63

Мотив мерења платна о црквена врата и зачињања веза или шаре са иконе присутан је и у сватовским песмама, које су у овом обреду прелаза намењене најчешће деверу.

\section{Краљичка \\ (dememy)}

Мајка Ристи кошуљу резала,

На ирквенска врата измерила,

Са иконе веза зачињала,

Са иконе, са свеиа Николе. ${ }^{64}$

У Херцеговини је ивањска песма са хришћанским мотивима везаним за празник рођења Светог Јована Крститеља, као и објашњење порекла ивањског цвећа:

\section{Ивањданска}

Дивна ли је Божја црква Софија!

У њој поју шестокрили анђели

Код юе дошла света дјева Марија,

Држ' у руке Христа Бога истина.

Говоре јој шестокрили анђели:

„,О тако ти света дјево Маријо!

„,Ти натргај Иванова ивијећа

„Пак отиди Крститељу Јовану

„И пред њим се кротко, смјерно поклони,

„Па му реци светоусне ријечи:

„, ,Кум да си ми Крститељу Јоване!

„,,Ти да крстиш Христа Бога истина.,"

Кад зачуо Крститељу Јоване,

Поклони се тер на ноге устаде,

Стаде крстит Христа Бога истина;

Тад се ведро небо над юим раствори

А ирна се земља махом затресе,

Док крстише Христа Бога истина. ${ }^{65}$

63 Златановић 1994, 80-81.

64 Поповић, 1888, 14.

65 Врчевић, 1888, 44; Караџић, 1975, 150; уп. Крстановић, 1990, 11, 13. 
„Кад је Богородица хтјела да окуми Светог Јована, она је узела киту ивањског цвијећа”, објашњење је које се приписује Вуку Врчевићу, који у књизи „Помање српске народне свечаности уз мимогредне народне обичаје”: „Најглавни је цвијет лијер” (бели крин) ${ }^{66}$, „који се у Боки Которској зове 'богородичино' (јер а. Гаврил држи овај цвијет на благовјештенској икони), а у Црној Гори 'иваново цвијеће"'. ${ }^{67}$ И у другом крају земље, околини Бољевца, посебно се значај придавао трави богородици, где су убране ивањске траве, ако ко треба лека, стављали у бакрач и кували, дајући их као чај или купајући тиме болесника: само се трава богородица никако не кува, већ се њоме само кади болесник. ${ }^{68}$

У народним песмама које се односе на страдање, васкрсење ${ }^{69}$ и вазнесење Христово, Пресвета Богородица заузима свакако важно место:

\section{Христос тјеши матер}

Душа лети, т'јело трепти

Под два крила анђеоска,

Под трећијем Исус био,

И овако говорио:

„Ко ће поћи украј пута,

„Украј пута светог крста,

„, Ту ће наћи мајку моју,

„, Бе пред крстом сузе рони,

„Сузе рони, Бога моли,

„Да јој јави сретье гласе.

„Како сам ја ускрснуо,

„На небеса полетио.”

То зачуо Свети Јово,

Па он посла два анђела,

Те анћели одлећеше,

Светој Госпи говорише:

'Не бој нам се, света мајко!

„Теб' је синак ускрснуо,

„На небеса полећео,

„Нас од гр'јеха избавио. "70

Како пише Дејан Ајдачић - „хришћанство је своја учења уносило у народ Библијом, црквеним списима ${ }^{71}$, фрескама, апокрифним делима, побожном књижевношћу, али је фолклорно хришћанство сачувало елементе паганских веровања". Канонски текстови, апокрифи и усменокњижевна традиција неминовно су се прожимали путевима усменог пријема. Нпр. мотив пакла ${ }^{72}$ се јавља у више сижеа ових паралелних система: посета Богородице и других светаца паклу, покушај спасавања грешника из пакла, најчешће мајке Светог Петра или Огњене Марије. Одређене разлике у националним и локалним традицијама произилазе из преплитања слојева сликовне, писане, усмене,

66 Ближе у Чајкановић, 1994, 23.

67 Врчевић, 1888, 42-43.

68 Према: Недељковић, 1990, 102.

69 Према Krstić, 1984, 40: В 2, 7, 1 Kad Hristos vaskrsne na nebo, anđeli i sveci igraju, a Božija majka kolo vodi.

70 Караџић, 1866, 326-327. Вид. још бр. 244. и 245. у истом извору.

71 Ајдачић, 2019. УП. Костић Тмушић, 2017, 33-42.

72 Требало би да се упореди како се у старој српској књижевности, која је превасходно црквена, као и у српском црквеном сликарству, гледа на пакао, а како у народној традицији. О овоме вид. Костић Тмушић, 2020, 13-30. 
обредне (црквене и народне) културе. У народним песмама и предањима Пресвета Богородица, Света Петка или Света Недеља, ређе неки други светац или анђели, траже кључеве раја да би из раја ушли у пакао. Богородицу најчешће замењује Света Петка, „митски алолик словенског божанства са атрибутима плетиље везане за судбину и хтонски свет". ${ }^{73}$ Оквир одласка Богородице или неке друге личности на онај свет, њено посматрање паклених мука и добијање објашњења за грехове због којих се те муке трпе, користи народна поезија, чиме се бавила Нада Милошевић-Ђорђевић проучавајући тематско-сижејне везе између народне прозе и неисторијских народних епских песама. Она народне песме о овој теми дели на четири важније групе. Прву чине епске песме, које почињу дијалогом са Богом, тражењем кључева и пратиоца за онај свет, а после виђења пакла, завршавају се најчешће моралном поуком. ${ }^{74}$ „Тежина казне у фолклорном паклу није једнака црквеној хијерархији грехова. Различитост казни у народним и црквеним веровањима, произилази из различитих осуда сагрешења по црквеном и обичајном праву."75 У другој групи, према подели Наде Милошевић-Ђорђевић, три грешника према варијанти може срести и Пресвета Богородица. Ове лирске песме се у потпуности поклапају са уводним делом епских варијаната прве групе. Као пример наводи лирску песму из Zbornika Matice hrvatske, I, 1896:

\section{Шетала се Христа Бога мајка А од раја до пакленских врата И с њоме су два Божја анђела \\ Кад у паклу три душище горе: \\ Једној горе ноге до кољена, Јер је туђе међе преорава; \\ Другој горе руке до лаката, Јер је тука своје родитеље; Трећој гори лишие до очију, Тај љубио на вјери дјевојку, Љубио је, пак је оставио, 76}

Централну тему треће групе народних песама према Нади Милошевић-Ђорђевић чини маћехино огрешење о пасторчад, а у четврту групу спадају песме, „у којима средишно место заузима грех одбијања милостиње, иначе, већ познат као епизода епских песама." $" 77$

„Морални систем цркве је у народним представама пакла допуњен гресима из народног поимања правде, а мање развијен у осудама греха у којима се оно није поклапало са Црквом. Пакао као место загробног испаштања грехова у хришћанској религији је приказан у канонским и неканонским списима, као и у црквеним и народним песмама и предањима. У апокрифном спису Ход Богородище по мукама описује се силазак Божје мајке са Арханђелом Михајлом у пакао. Међутим, важна је чињеница да, човек народне културе, недовољно упућен у хришћанску естетику и догматику, допуњује и преображава те слике према фолклорном поимању загробног света."궁

73 Ajdačić, 2019. „У песмама о силаску Свете Петке и Свете Недеље у ад, светице виде и грешнике који испаштају због непоштовања њихових дана”. Вид. Митић, 2018, 371-378.

74 Милошевић-Ђорђевић, 1971, 206.

75 Ajdačić, 2019.

76 Према: Милошевић-Ђорђевић, 1971, 207.

77 Исто.

78 Ajdačić, 2019. 


\section{Пресвета Богородица у усменопрозној традицији}

Важно је овде да се нагласи да ,у народном приповедању и народном погледу на свет не постоји чврсто разграничење Старог и Новог завета, јер се Библија схвата као јединствена света књига. Човек народне културе није имао потребу нити знања да одваја ликове старијег и новијег библијског дела. У томе су му били блиски апокрифни списи, који више повезују но (што) раздвајају Стари и Нови завет."79

Готово све народне приче, у којима се појављује Пресвета Богородица, везане су за апокрифе. Апокрифи и усменокњижевна традиција преплићу занимљиве и лако памтљиве заплете. Мотиви скопчани са Пресветом Богородицом, проистекли из апокрифних списа, слични су и својствени фолклору јужнословенских народа. ${ }^{80}$

„Према истакнутом обележју да је родила Христа, Богородица је постала покровитељка породиља и свих жена које желе да имају пород." 11 Карактеристична особина Богородице у здравицама балканских Словена је „живоначелна”, „која може да нам поможе”; „нас се сетила”; „најбоља нам помоћница била”; „спасла нас”; 82 Слично је и у бајкама, Богородица се јавља као спаситељка: „Најбогатији круг варијанта бајки записаних у Вили”, како запажа Снежана Самарџија, „окупљен је око фабуле о прогоњеним јунацима - деци, девојци, младој жени и њеном чудесном породу (AaTh 327, 706, 707). [...] Управо запис из Виле (6. Бог не заборавља правих 83 , AaTh 709, I, II + 706) послужио је Павлу Поповићу да прикаже идеалан тип бајке о девојци без руку. Потанко изложивши радњу, пратио је сличности и разлике фолклорних обрада са могућим писаним изворима у делу светогорског монаха Агапија и српскословенским преводима Чудеса Богородице." 84 У једној народној приповеци Богородица спасава жену коју је муж хтео да преда ђаволу за обећано богатство, тако што узима њен лик и клетвом ђавола претвори у прах и пепео (Ресава). ${ }^{85}$

Највећи број усмених предања повезаних са Пресветом Богородицом налазимо у области етноботанике. Нпр. Богородичина трава (Госпина трава, кантарион) ${ }^{86}$, „Код нас се ова мирисава биљка у народу веома употребљује као лек од разних болести. Зато је наш народ и доводи у везу са Небесном Царицом, помагачицом и заштитиницом свију невољних. У околини Ниша народ називље ову биљку Богородичиним тестом и за ово

79 Ајдачић, 2005, 288.

80 У Македонији се проблемом односа апокрифа и народне традиције бавила Вера Антић Стојчевска, у Бугарској Донка Петканова Тотева и Цветана Вранска, последња особито новозаветним апокрифима посвећеним Богородици.

$81 \mathrm{CE}, 2011,270$.

82 Петровић, 2006, 173.

83 Варијанте: Вук, СНП, бр. 33, Зла маћеха; ЛМС, 1858, 97, стр. 165-172, Маћеха и пасторка (АаТh 706 + 707; о прогоњеној девојци - девојци без руку: повезано са приповедним типом о прогоњеној невести и њеној деци); ЛМС, 1876, 119, стр. 177-180, Како ко ради онако и пролази, у ЛМС бр. 8, 9 и напомене на стр. 210-211; Алексић, IV, Бакарна коза; Којанов, СНП, 18, Девојка којој на глави ружа цвати, за юом трава расте и ту траву златан коњ пасе; Микуличић, стр. 57-68, Devojke kaplju zoči dijamanti, kad se plače, a kad se smeje, rožice z usta; Strohal, I, 4, Kako je vrag pisma prepisival, 2, O grofovoj ženi i dici (са мотивом замењеног писма); Красић СНП, І, бр. 1, Десета кћu; Николић, СНП, бр. 9, Царииа са звездом на челу. Чајкановић, Антологија, 193 и напомена на стр. 411. Занимљиво је да Чајкановић варијанту из Виле укључује међу легенде, а не у корпус бајки, директно је означавајући као „нежну легенду”.

84 Самарџија, 2009, 15. Вид. П. Поповић, 1905, 25, 99-100. Уп. Поленаковиќ, 1988, 415-434.

85 Према СЕ, 2011, 270.

86 Videk, 1960, 130-131. 
име везује причу: 'Једном Богородица, пошто је месила хлеб, умије своје руке од теста, па су капљице такове воде падале на ову биљку. Отуда је биљка добила оне беле пеге које се вићају на њеном широком лишћу’." ${ }^{87}$ У речнику Веселина Чајкановића налази се и овај податак: „Ако жена услед чини не може да затрудни, треба духовник да благослови Госпину траву; трава се затим скува и неколико дана пије изјутра наштину. Сем тога, жена ову траву треба да носи уза се. У народној медицини Богородичина трава се употребљава код застарелог кашља и астме, кад је поремећена менструација, код тешког порођаја, кад кога боли утроба, меће се на осекотину, против беснила. Понекад се њоме само кади болесник, а никако се не кува. Нарочиту снагу има она убрана на Ивањдан." 88

Или о босиљку: користио се и користи се као антисептик и зачин. „Једна хришћанска легенда у нашем народу вели о њему да је први пут никао на Голготи, где је Христос Спас био разапет. А опет једна друга легенда, по свој прилици у вези с оном горњом легендом, вели, да је Мајка Богородица најрадије мирисала босиљак, и да јој је био најмилији цветак." 89 Босиљак је имао широку примену у враџбинама и народној медицини. „Семеном од босиљка лечи се врућица и кијавица. У води у којој је босиљак потопљен купају се болесници од велике болести. Његов сок употребљује се против змијског уједа, исто тако босиљак се привија кад уједе чела или зоља [...] Мирисање сувог босиљка помаже очном виду [...] Да би се жена лакше породила, треба да пије воду са крстовданским босиљком, нарочито још ако је на Крстовдан украден са иконе."

У Херцеговини се причало етиолошко предање о постанку обичаја да се на Божић кити кућа бршљаном: „Кад је Ирод наредио покољ деце, онда су Јевреји, идући из куће у кућу, метнули бршљанову грану на сваку кућу где су дете погубили, да се не би поново у ту кућу навраћали. И онда је на кући у којој је био Исус изненада изникао бршљан, и тако је Исус спасен, а нама остао обичај да се о Божићу кити кућа бршљаном." ${ }^{1}$

Са друге стране „у околини Ниша прича се да је здравац постао од Богородичиног зноја, који је капао на земљу када је по брдима и врлетима бежала са новорођеним Исусом. У народној медицини здравац дејствује углавном егзорцистички, мање као медикамент. При магичном 'отварању' болесника, болесник мора бити окупан у води у којој је преноћио здравац. Породиља одмах по порођају треба да се окупа у води са здравцем." 92

Словенци верују да у липу не удара гром зато што се под њом одморила Богородица кад је бежала са Исусом. ${ }^{93}$ У околини Ниша се верује да је Богородици кад је бежала с новорођеним Христом упомоћ притекла купина, која је на Богородичину молитву гониоца саплела и задржала. ${ }^{94}$ Када је Богородица бежала са Исусом, жалосна врба се сажалила на њу и спустила своје гране да би је сакрила, отуда су јој гране оборене, и отуда се зове жалосна. Топола се оглушила о Богородичине молитве, зато ју је Богородица проклела да јој се лишће увек лелуја, и без ветра. ${ }^{95}$ „Зашто је клас пшенице мали као шака? Једном је ђаво упалио пшеницу, и она почне горети; Богородици би жао,

87 Софрић Нишевљанин, 1990, 13-14. Уп. Катић, 1982, 93.

88 Чајкановић, 1994, 31-32, 222-223. Уп. Симоновић, 1959, 241-242; Tucakov, 1960, 68-69; Сикимић, 2014, 132.

89 Софрић Нишевљанин, 1990, 29-45. Уп. Катић, 1982, 85; Раденковић, 1996, 214-215.

90 Чајкановић, 1994, 36-43, 223-224. Уп. Симоновић, 1959, 320-321; Tucakov, 1960, 64.

91 Чајкановић, 1994, 49-50, 225. Уп. Симоновић, 1959, 224; Tucakov, 1960, 64-65.

92 Чајкановић, 1994, 86-87, 233. Уп. Софрић Нишевљанин, 1990, 100-101; Симоновић, 1959, 212-213; Tucakov, 1960, 88; Сикимић, 2014, 130.

93 Према: Чајкановић, 1994a, 463.

94 Софрић Нишевљанин, 1990, 144.

95 Lovretić, 1902, 195. 
па сиђе с неба, ухвати шаком за клас и угаси ватру: и клас остане онолики колико је Богородица ухватила."96

Занимљиво је да „на особен начин, потпуно подређене одређеном типу фантастике, животиње се укључују и у структуру легендарне приче и у динамику чудесних авантура бајке. Легенде махом апсорбују етиолошка предања, тумачећи настанак и својства живих бића кроз потврду моћи демона, Божје воље, снаге Богородичиних речи и чудеса светаца."97

„Мада су вегетацији, домаћим и дивљим животињама, птицама, гмизавцима и инсектима намењене другачије казне, неминовне су и трајне последице преступа. [...] Богородица проклиње коња да се никада не наједе, јер узима сламу на којој је положен тек рођени Исус (Зашто се коњ не може никад најести, Врчевић, СНП II, стр. 77-78). Клетва Божије мајке стиже и јасику чије лишће увек трепери, јер се једино она није умирила за време појања светаца (Чајкановић, 1985, 122). Проклетство пада и на тополу, када не заштити пчелу пред Дабоговом потером, али су зато због пруженог уточишта благословени босиљак и тамњаново дрво (Вила, 18) итд."98

Предање о чудотворности Појаса Пресвете засновано је на библијској и митској симболици. Може се рећи да предање има упоришну тачку у библијској симболици, али га је створила и одржала врло древна митолошка представа која се у народној култури Балкана одржала све до данас. По народним представама за неплодност у браку је крива жена и, обично, она предузима магијске радње које треба да јој омогуће плодност (као што су: провлачење испод шупљих каменова, обилажење култних каменова, ритуално купање и сл.) Овде је пак то проблем супружника јер пород треба схватити као дар Божји, који траже и добијају жена и муж држећи се одређених правила понашања.

За расветљавање митолошке слике осим народних представа важан је симболички елеменат: везивање на основу предања Свете Горе за Богородицу. По предању, после Христовог узнесења на небо, апостоли заједно са Богородицом, бацањем коцке, делили су земље у којима ће обављати проповед. Богородица је добила Иверску, тј. Ђурђијанску земљу, али анђео по Божјој жељи мења њен пут и одводи је на Атос, који она, од паганског претвара у свето хришћанско место. И после осам векова она се јавља пустињаку Светом Петру и њему објављује да је Света Гора њена. По предању Пресвета Богородица посетила је Халкидики и оставила завет да источни крак полуострва буде њена држава. 99

Пресвета Богородица је у апокрифима мотивски заступљена као: „анђелска похвала”, „она која благосиља”, „виша од свих”, „заступница хришћанска”, „зрака незалазне светлости”, „молитвеник”; „омофор њен”, „појас њен”, „покров њен”, „родитељи њени”, ,рођење њено”, „Синовљево станиште”, „ход њен”, „пловљење њено”, „четворострука тврђава”, „успење њено”100, „Ход Богородице по мукама” (обе верзије), „Како апостол Тома подиже панагију” (обе верзије), „О часном крсту и о два разбојника” (друга верзија), „Слово Јована Богослова о Богородичином успењу”, „Протојеванђеље

96 Стојановић, 1901, 136.

97 Самарџија, 2011, 99.

98 Исто.

99 Уп. СЕ, 2011, 268.

$100 \mathrm{AH}, 2005,553$. 
Јаковљево”, „Анастасија црноризица”, „Како се написа Јеванђеље”, „Сказање Афродитијана Персијанца” (краћа верзија), „О сплетеном дрвету”. 101

Апокрифе су народни певачи и казивачи прилагодили правилима усменокњижевних творевина у којима мотивски: „Богородица рађа Христа из груди”, „прави љуљку да љуља Христа”, „куне и благосиља биљке и животиње”, „моли Христа да помогне жени која се мучи на порођају”, „доји дете чија је мати умрла”, „опомиње девојку да свекрва хоће да је отрује”, „ослобађа сужња из тамнице”, „одводи мученицу на небо”, „кажњава бродаре”, „каже Христу да казни ходочаснике што играју”, „проклиње Цигане што кују Христу велике чавле”, „проклиње ловце”, „пише цару Лазару да бира између небеског и земаљског царства”, „пише раји у Херцеговину да се диже на оружје”, „извештава калуђере да ће Турци напасти манастир”, „Богородица се заузима за грешне душе”, „саветује девојку како ће свирком избавити родитеље из пакла”; побројана су чуда Богородице: „море се пред њом разлије, а за њом залије”, „хода по реци”, „оживљава растргнуту девојку”, „окамени Јевреје што хоће да јој отму Христа”, „лечи крвљу детета слепе, неме и кљасте, па оживљава исто дете”, , јавља се у виду птице”, ,уда се за Јосифа јер у његовој руци процвета штап". 102

Народни култ Пресвете Богородице разликује се од црквеног већом обичношћу и укљученошћу у свакидашњи живот, ближи је некакнонским текстовима и однегован на основу њих. Пресвета Богородица је у усменокњижевну традицију стигла из апокрифне литературе, а потом су мотиви скопчани с њеним животом прерађени у народној свести и прилагођени народном веровању и народној традицији, па се могу повезивати са старим веровањима у оквирима митологије и фолклорне фантастике. Постоје и самосвојни теотоколошки мотиви у поезији и прози усменокњижевног постања, тј. они настали потпуно независно од апокрифа.

\section{Извори}

АН (2005): Апокрифи новозаветни, приредио и превео др Томислав Јовановић, Београд: Просвета, Српска књижевна задруга.

Антонијевић, Драгослав (1971): Алексиначко Поморавље, у: Српски етнографски зборник 83.

Ardalić, Vladimir (1915): Godišńi običaji (Bukovica u Dalmaciji), Zbornik za narodni život i običaje Južnih Slavena, 20, sv. 1, 32-52.

Boranić, Dragutin (1912): Iz života turskih sužńeva, Zbornik za narodni život i običaje južnih Slavena, 17, sv. 1, 186-190.

БХ (1958): Банатске Хере, ур. Миленко С. Филиповић, Нови Сад: Војвођански музеј.

Брканлија Касаблија (1903): Обичаји у Сарајеву, Караџић, IV, 3, 165-171.

Васиљевић, Миодраг А. (1950): Југословенски музички фолклор I, Београд: Просвета.

Веселиновић, Јован Х. (1890): Лазарище, српски народни обичај у Врању и врағском округу, Браство, IV, 66-94.

Videk, Vilko (1960): Ljekovito bilje Jugoslavije, Zagreb: Poljoprivredni nakladni zavod.

101 Уп. АН, 2005, 547-548.

102 Krstić, 1984, 465. 
Врчевић, Вук (1888): Помање српске народне свечаности уз мимогредне народне обичаје. Сабрао по Боки Которској, Црној Гори и Ерцеговини и у реду описао, Панчево: Браћа Јовановић.

Грбић, Саватије М. (1909): Српски народни обичаји из среза бољевачког, у: Српски етнографски зборник 14, 1-382.

Димитријевић, Дим. (1901): Некоја веровања и обичаји у Неготинској Крајини, Караџић, III, 12, 234-239.

Димитријевић, С. (1987): Народне песме лесковачког краја. Свеска прва, Лексовачки зборник XXVII, 3-59.

Ђорђевић, Драгутин М. (1958): Живот и обичаји народни у Лесковачкој Морави, у: Српски етнографски зборник 70.

Ђорђевић, Драгутин М. (1990): Народне песме из лесковачке области, у: Српски етнографски зборник 95.

Ђорђевић, Тихомир Р. (1899): Народна имена месеща, Караџић, I, 3-4, 77-78.

Ђорђевић, Тихомир Р. (1958): Природа у веровању и предању нашега народа, II, Српски етнографски зборник 72.

Jovićević, Andrija (1928): Godišnji običaji (Riječka nahija u Crnoj Gori), Zbornik za narodni život i običaje južnih Slavena, 26/2, 293-318.

Караџић, Вук Стеф. (1866): Српске народне пјесме из Хериеговине: женске. Беч http://digital.bms.rs/ebiblioteka/pageFlip/reader/index.php?type=publications\&id=1154\&m=2 \#page/12/mode/2up (12. 5. 2021)

Караџић, Вук Стеф. (1972): Етнографски списи. Сабрана дела Вука Караџића XVII, Београд: Просвета.

Караџић, Вук Стеф. (1975): Српске народне пјесме. Книга прва, 1841. Сабрана дела Вука Караџића IV, Београд: Просвета.

Караџић, Вук Стеф. (1986): Српски рјечник (1852). Сабрана дела Вука Караџића XI, Београд: Просвета.

Катић, Реља (1982): Терминологија средњовековне српске медииине, Београд: CAHY

Krstić, Branislav (1984): Indeks motiva narodnih pesama balkanskih Slovena, Beograd: SANU.

Крстановић, Здравко (1990): Златна пјена од мора. Народне пјесме Срба у Хрватској, Београд: Рад.

Lovretić, Josip (1902): Otok. Narodni život i običaji, Zbornik za narodni život i običaje južnih Slavena, 7, 57-201.

Мијатовић, Станоје М. (1907), Обичаји народа српског у Левчу и Темнићу, у: Српски етнографски зборник 7, 1-170.

Милићевић, Милан Ђ. (1984): Живот Срба сељака, Београд: Просвета.

Милосављевић, Сава (1914): Српски народни обичаји из среза хомољског, у: Српски етнографски зборник 19, 1-442.

Мићовић, Љубо (1952): Живот и обичаји Поповаца, у: Српски етнографски зборник 65.

Николић, Владимир (1900): Нешто из народног празновања: (у округу Пиротском), Караџић, II, 5, 89-91.

Павловић, Јеремија М. (1921): Живот и обичаји народни у Крагујевачкој Јасеници, у: Српски етнографски зборник 22.

Петровић, Атанасије (1907): Обичаји народа српског у Скопској Црној Гори, у: Српски етнографски зборник 7, 171-332. 
Петровић, Петар Ж. (1934): Живот и обичаји народни у Гружи, у: Српски етнографски зборник 58, 1-275.

Поп Дена Дебељковић (1948): Обичаји народа српског на Косову Пољу, у: Српски етнографски зборник 7.

Самарџија, Снежана (1995): Народне приповетке у Летопису Матице српске, Нови Сад: Матица српска.

Самарџија, Снежана (2009): Народна проза у Вили, Нови Сад: Матица српска.

CE (2011): Српска енциклопедија, том I, књига 2, Чедомир Попов, Драган Станић, ур., Нови Сад: Матица српска, Београд: САНУ, Завод за уџбенике и наставна средства.

Симоновић, Драгутин (1959): Ботанички речник, Београд: САНУ, ИСХЈ.

СМЕР (2001): Словенска митологија. Енциклопедијски речник, ред. Светлана Толстој, Љубинко Раденковић, Београд: Zepter book world.

СМР (1998): Српски митолочки речник, Шпиро Кулишић, Петар Ж. Петровић, Никола Пантелић, ур., Београд: Етнографски институт САНУ.

Софрић Нишевљанин, Павле (1990): Главније биље у народном веровању $и$ певану код нас Срба, Београд: БИГЗ.

Стојановић, Михаило (1901): Животиње и биље у народном предању, Караџић, III, 6-7, 136.

Tucakov, Jovan (1960): Lekovito bilje, Novi Sad: Progres.

Урошевић, Атанасије (1990): Косово, у: Српски етнографски зборник 78.

Филиповић, Миленко С. (1934): Обичаји и веровања у Скопској котлини, у: Српски етнографски зборник 54, 277-566.

Филиповић, Миленко С. (1949): Живот и обичаји народни у Височкој нахији, у: Српски етнографски зборник 61.

Филиповић, Миленко С., Томић, Персида (1955): Горња Пчиња, у: Српски етнографски зборник 68.

Чајкановић, Веселин (1994): Речник српских народних веровања о биљкама, Београд: СКЗ, БИГЗ, Просвета, Партенон.

Шкарић, Милош Ђ. (1934): Живот и обичаји планинаца под Фрушком гором, у: Српски етнографски зборник 54, 1-275.

\section{Литература}

Ајдачић, Дејан (2005): Старозаветне легенде у фолклору православних балканских Словена, Црквене студије II, 287-297.

Ajdačić, Dejan (2019): Predstave o hrišćanskom paklu u folkloru balkanskih Slovena. https://www.rastko.rs/rastko/delo/10044 (12. 5. 2021)

Антиќ-Стојчевска, Вера (1970): Мотиви што се среќаваат во апокрифната и во народната литература, Македонски фолклор, 3-4, 195-208.

Антиќ-Стојчевска, Вера (1978): Од есхатолошките апокрифи за Богородица и нивниот одлив во народното творештво на југословенските народи, Македонски фолклор, 2, 207-218.

Vitković, Dimitrije (1919): Utjecaj hrišćanske ikonografije na neke narodne pjesme, Zbornik za narodni život i običaje južnih Slavena, 24, 1-28.

Вранска, Цветана (1940): Апокрифитг за Богородица и българската народна пгосень, София: Дьржавна печатница.

Јокић, Јасмина (2012): Краљичке песме. Ритуал и поезија, Београд: Друштво за српски језик и књижевност Србије. 
Костић Тмушић, Александра (2017): Поетски елементи у српској хагиографској књижевности, Косовска Митровица, Ниш: Филозофски факултет, Међународни центар за православне студије.

Костић Тмушић, Александра (2020). Мотиви покајања и страшног суда у књижевности и сликарству за време краља Милутина. У: Наука без граница III, Косовска Митровица: Филозофски факултет, 13-30. Београд: СКЗ.

Љубинковић, Ненад (2014): Наши далеки преци. Етномитолошке студије,

Милошевић-Ђорђевић, Нада (1971): Заједничка тематско-сижејна основа српскохрватских неисторијских епских песама и прозне традиције, Београд: Филолошки факултет Београдског универзитета.

Мршевић Радовић, Драгана (1987): Фразеолошке глаголско-именичке синтагме у савременом српскохрватском језику, Београд: Филоолошки факултет.

Митић, Кристина (2018): Светитељке које пазе на женске послове, у: Византијско-словенска чтенија I, Ниш: Центар за византијско-словенске студије, 371-378.

Митић, Кристина (2018): Не боје се ока ни урока, Зборник радова Филозофског факултета, XLVIII, 2, 229-247.

Петканова-Тотева, Донка (1978): Апокрифна литература и фолклор: апокрифната художествена проза и фолклорът, София: Наука и изкуство.

Петровић, Петар Ж. (1932): Опасивање цркава, Гласник Етнографског музеја VII, $110-112$.

Петровић, Тања (2006): Здравиияа код балканских Словена, Београд: Балканолошки институт САНУ.

Поленаковиќ, Харалампие (1988): Студии од македонскиот фолклор, Скопје: Македонска книга.

Раденковић, Љубинко (1996): Симболика света у народној магији јужних Словена, Београд, Ниш: Просвета.

Самарџија, Снежана (2011): Облици усмене прозе, Београд: Службени гласник.

Сикимић, Биљана (2014): Антрополочко-лингвистички речник лековитог биља: Къажевач и околина. У: Биље у традиционалној култури Срба. Приручник фолклорне ботанике II, (ур. Зоја Карановић), Нови Сад: Филозофски факултет, 125-143.

Чајкановић, Веселин (1994а): Студије из српске религије и фолклора 1925-1942, Београд: Српска књижевна задруга, БИГЗ, Просвета, Партенон.

Чајкановић, Веселин (1994б): О врховном богу у старој српској религији, Београд: Српска књижевна задруга, БИГЗ, Просвета, Партенон.

Чајкановић, Веселин (1994в): Стара српска религија и митологија, Београд: Српска књижевна задруга, БИГЗ, Просвета, Партенон. 


\section{Aleksandra Kostić Tmušić \\ Kristina Mitić}

\section{HOLY MOTHER OF GOD IN THE ORAL LITERARY TRADITION}

The popular cult of the Holy Mother of God differs from the church cult by its greater commonness and involvement in everyday life. The Holy Mother of God is repeatedly represented in the New Testament apocrypha; those motifs are reflected in the indices of motifs of the oral literary tradition. 